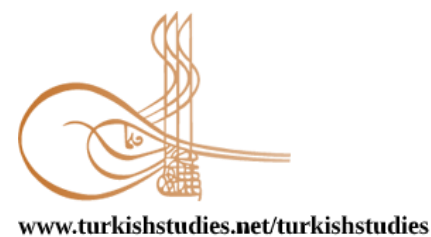

Turkish Studies

\title{
Covid-19 Sürecinde E-Ticaret Sitelerine Yöneltilen Müşteri Şikâyetlerinin İncelenmesi
}

\author{
Investigation of Customer Complaints Directed to E-Commerce Sites in Covid-19 Process
}

\author{
Hüseyin Güven*
}

\begin{abstract}
The epidemic caused by the coronavirus, which emerged in Wuhan, China in December 2019, affected the whole world in terms of health and economy. While many businesses are negatively affected by this epidemic disease, an increase is observed in the world of e-commerce. E-commerce sites, which are increasing in number of users every day during the epidemic, have become attractive for shopping due to curfews and consumers are afraid to get coronavirus disease. As a matter of fact, e-commerce websites had difficulties in meeting the increasing demand in this period and disruptions occurred in the services provided. These disruptions caused dissatisfaction with customers and customers started to express their dissatisfaction by complaining. It is important to consider and resolve these complaints, to ensure customer satisfaction and to gain customer loyalty. In line with all this, the purpose of this study is to examine the complaints addressed to e-commerce sites during the Covid-19 pandemic crisis. Research has been done on which operates in Turkey and three e-commerce sites selling products in different categories. The research was designed qualitatively and document analysis was used as a data collection method. The data used in the research were obtained from sikayetvar.com website. The analysis of these data was done through the MAXQDA qualitative research program. As a result of the research, it was concluded that the issues that the customers had the most problems respectively were the complaints about the customer service / live support and delivery process, while the least complained main theme was the order process.
\end{abstract}

Structured Abstract: Introduction: With the outbreak of the Covid-19 pandemic crisis and increasing its impact, the shopping activities of consumers have started to change. Before the epidemic, the shopping made in the shopping centers such as markets and stores started to shift to e-commerce with the increase of the epidemic. With the increase in the direction of e-commerce due to the epidemic, it has become difficult to meet the demand intensity. Especially in this period, there have been significant increases in customer complaints regarding e-commerce sites. In e-commerce sites, customer complaints arise if customers are not satisfied with the service they receive and their expectations are not met. It is seen as an important method to consider these complaints, to resolve them, to ensure customer satisfaction and to gain customer loyalty.

Purpose and Importance of the Study: The aim of this study is to examine the complaints directed to e-commerce sites during the Covid-19 pandemic crisis. The findings obtained as a result of the study are thought to guide e-commerce site managers in the context of identifying sources of dissatisfaction with customers who use e-commerce sites and organizing service delivery plans accordingly.

*Dr., Karabağlar Rehberlik ve Araştırma Merkezi.

Dr, Karabaglar Guidance and Research Center.

ORCID 0000-0003-1816-6415

huseyin0709@gmail.com

Cite as/ Atıf: Güven, H. (2020). Covid-19 sürecinde e-ticaret sitelerine yöneltilen müşteri şikâyetlerinin incelenmesi.

Turkish Studies, 15(4), 511-530. https://dx.doi.org/10.7827/TurkishStudies.44354

Received/Geliş: 19 June/Haziran 2020

Accepted/Kabul: 25 August/Ağustos 2020

Checked by plagiarism software

Copyright (C) MDE, Turkey

Published/Yayın: 30 August/Ağustos 2020

CC BY-NC 4.0 
Methods: Research has been done on which operates in Turkey and three e-commerce sites selling products in different categories. Complaints about the e-commerce sites to be investigated were examined and interpreted. The research has been designed qualitatively and document analysis has been used as a data collection method. The data obtained from the e-commerce sites were taken from the sikayetvar.com platform. Content analysis technique was used to organize the collected data and to identify the main and sub-themes announced.

The data obtained were analyzed through the MAXQDA qualitative research program. At this stage, complaint texts were analyzed, coding was made for each complaint and the data were categorized. While creating the categories, coding was done considering the complaint issues. As a result of this coding, complaints are examined and themed one by one; the theming process and the creation of a sub-theme started; It is divided into multiple main and sub-themes. As a result, 5 main themes and 23 sub-themes were created.

Since there is no different data from the themes determined in the research and the scope of the data reached is represented effectively, the research is consistent. Intense and long-term relevance is an important issue in the validity of the research. In this study, the researcher dealt with long-term complaints and complaints were reviewed repeatedly during the coding process. Evidence from different sources has been obtained to support the validity of the study. It was observed that the complaints in the reviewed sources were similar to those in the research. In addition, two experts, who are experts in their fields, were asked about the process of the study. This contributed to the validity of the research.

Findings: When the complaints coming to e-commerce sites are evaluated in terms of main themes, it is seen that the main themes in which customers have the most problems are the complaints about customer service / live support and delivery process, while the least complained is the main theme order process. Complaints about the three e-commerce sites are determined as the failure of the orders, the product not to be delivered to the cargo on time, the lack of sufficient solution to the complaints and the refusal of return requests.

Conclusion and Suggestions: When the complaints received in e-commerce sites were evaluated in terms of main themes, it was seen that the main themes in which the customers had the most problems were the complaints related to customer service / live support and delivery process, while the least complained main theme was the order process. In the occurrence of these results, it can be said that due to the increase in the trend towards e-commerce during the epidemic period and the delay in the product supply process due to this increase, the products were delayed. In addition, delays in the delivery of the cargoes due to the intensity of the cargo companies have an important role in receiving these complaints. Coordinated development of ecommerce companies in these areas and keeping the communication with the companies providing logistics alive may reduce the intensity of complaints. In addition, increasing the number of customer representatives / people working in live support and granting broader powers to the representatives working in this section may also have a significant share in reducing complaints, in order to reduce the problems experienced by the employees regarding customer service. Because the managers of e-commerce companies have to learn about the reasons of customer dissatisfaction and engage in various activities and arrangements that focus the customer on the way to satisfy the customers.

Keywords: Marketing, Covid-19, Coronavirus, E-Commerce, Customer Complaints, Maxqda

Öz: 2019 yılının Aralık ayında Çin'in Wuhan şehrinde ortaya çıkan Koronavirüsün sebep olduğu salgın hastalık, tüm dünyayı sağlık ve ekonomik anlamda etkilemiştir. Birçok işletme bu salgın hastalıktan olumsuz etkilenirken e-ticaret dünyasında ise bir artışın olduğu görülmektedir. Salgın döneminde her geçen gün kullanıcı sayısı artan e-ticaret siteleri sokağa çıkma yasakları ve tüketicilerin koronavirüs hastalığına yakalanmaktan çekinmeleri sebebiyle alışveriş yapmak için cazip hale gelmiştir. Nitekim e-ticaret siteleri bu dönemde artan talebi karşılamakta zorlanmış, verilen hizmetlerde aksamalar meydana gelmiştir. $\mathrm{Bu}$ aksaklıklar müşterilerde memnuniyetsizlik yaratmış ve müşteriler memnuniyetsizliklerini şikâyette bulunarak ifade etmeye başlamışlardır. Bu şikâyetlerin dikkate alınması ve çözülmesi, müşteri memnuniyetinin sağlanarak ve müşteri sadakatinin kazanılması önemlilik arz etmektedir. Tüm bunlar doğrultusunda bu çalışmanın amacı Covid- 19 pandemik krizi sırasında e-ticaret sitelerine yöneltilen şikâyetlerin incelenmesi oluşturmaktadır. Araştırma Türkiye'de faaliyetlerini sürdüren ve farklı ürün kategorilerinde satış yapan üç e-

Turkish Studies, 15(4) 
ticaret sitesi üzerinde yapılmıştır. Bu e-ticaret sitelerine ilişkin şikâyetler incelenmiş ve yorumlanmıştır. Araştırma nitel olarak kurgulanarak, veri toplama yöntemi olarak doküman incelemesi kullanılmıştır. Araştırmada kullanılan veriler, sikayetvar.com web sitesinden elde edilmiştir. Bu verilerin analizi MAXQDA nitel araştırma programı aracılığıyla yapılmıştır. Araştırma sonucunda müşterilerin sırasıyla en fazla sorun yaşadığı konuların müşteri hizmetleri/canlı destek ve teslimat süreci ile ilgili şikâyetler olduğu görülürken, en az şikâyet edilen ana temanın ise sipariş süreci olduğu sonucuna ulaşılmıştır.

Anahtar Kelimeler: Pazarlama, Covid-19, Koronavirüs, E-Ticaret, Müşteri Şikâyetleri, Maxqda

\section{Giriş}

2019 yılının Aralık ayında Çin'in Wuhan şehrinde ortaya çıkan ve COVID-19 olarak isimlendirilen Koronavirüsün sebep olduğu salgın hastalık, kısa süre içerisinde dünya genelinde sağlık ve ekonomik anlamda olumsuz etkilere sebep olmuştur. 12 Haziran 2020 itibariyle, yeni koronavirüs toplam 7.410.510 onaylanmış vakaya ve 418.294 ölüme neden olmuştur (WHO, 2020a). Dünya Sağlik Örgütü (WHO) 11 Şubat 2020' de COVID-19'u salgın olarak ilan etmiştir (WHO, 2020b). 12 Haziran 2020 tarihi itibarı ile Türkiye'de sağlık bakanlığı verilerine göre 175.218 onaylanmış vaka ve 4.778 ölüm bildirilmiştir (TC Sağlık Bakanlığı, 2020).

Koronavirüs pandemik krizinin patlak vermesi ve etkisini giderek artırmasiyla birlikte tüketicilerin alışveriş aktiviteleri değişim geçirmeye başlamışıır. Salgın öncesinde genel olarak marketler, mağazalar gibi alışveriş merkezlerinden yapılan alışverişler salgının artmasıyla birlikte daha çok e-ticarete kaymaya başlamıştır. E-ticaretin koronavirüs salgını döneminde artmasında alışverişin pratik olması, tüketicilerin istediği ürüne hızlıca ulaşabilmesi, sürekli kampanya ve indirimlerin yapılması, nakit para ve pos cihazı ile temas kurulmadan ödeme imkânı sağlaması, ürün çeşitliliğinin fazla olması ve en önemlisi evden çıkmadan alışveriş sürecinin gerçekleştirilmesi gibi sebepler gösterilebilir (Digitalplanet, 2020).

Salgın nedeniyle e-ticarete yönelimin artmasıyla birlikte yaşanan talep yoğunluğunu karşılamak zorlaşmaya başlamıştır. Özellikle bu dönemde e-ticaret sitelerine yönelik müşteri şikâyetlerinde önemli artışlar meydana gelmiştir. Müssterileri memnun etmek geleneksel ticarette olduğu gibi e-ticaret sektöründeki işletmelerin başarısında önemli bir unsurdur. İşletmelerin büyümesi, pazar payını arttırması ve uzun dönemli müşteri ilişkileri kurabilmesi müşteri memnuniyeti açısından önem arz etmektedir (Patterson vd., 1997:4).

E-ticaret sitelerinde müşteriler almış oldukları hizmetten memnun kalmaması ve beklentilerinin karşılanmaması durumunda şikâyet davranışı göstermeye başlarlar. Bu şikâyetlerin göz önünde bulundurulması, çözülmesi, müşteri memnuniyetinin sağlanması ve müşteri sadakatinin kazanılması önem arzetmektedir (Gökdeniz vd., 2011:174). E-ticaret sitesi yöneticilerinin müşteri şikâyetlerine karşı duyarlı olması ve hızlı bir şekilde karşılık vermesi eticaret siteleri için kritik bir önem taşımaktadır.

Ürün ya da hizmetle ilgili, tüketicinin katlanamadığ deneyimler, şikâyetin ortaya çıkmasına yol açar. Müşterilerin şikâyet etmesinin sebeplerinin ve sonuçlarının önemini kavramak ve bu doğrultuda düzenlemeler yapmak, rekabetin hüküm sürdügü e-ticaret sektöründe işletmeleriçin çeşitli avantajlar sunmaktadır (İbiş vd. 2019:506). Şikâyet eden müşterilerle profesyonel olarak ilgilenilir ve şikâyeti çözümlenirse, alışveriş süreciyle ilgili sorun yaşamayan bir müşteriden işletmeye daha sadık bir müşteriye dönüşmesi olağandır (Kutluk ve Arpac1, 2016).

Teknolojinin gelişimi ve artan müşteri beklentileri sebebiyle e-ticarette müşterilerin eticaret siteleri ile kurdukları ilişki önemlidir. Rekabet koşullarında e-ticaret sitelerinin müşterilerini koruyabilmeleri ve yeni müşteri kazanabilmeleri için müşterilerin e-ticaret sitelerinden beklentilerinin karşılanması öncelikle ele alınması gereken bir konudur. Tüm bunlar doğrultusunda 
bu çalışmanın amacı Covid- 19 pandemik krizi sırasında e-ticaret sitelerine yöneltilen şikâyetlerin incelenmesi oluşturmaktadır. Çalışma, tüketicilerin şikâyetlerini paylaştığı, kullanıcı sayısı yüksek olan sitelerden olan sikayetvar. com'da yayınlanan şikâyetlerin içerik analiziyle gerçekleştirilmiştir. Şikâyetlerin belirlenmesi ile e-ticaret sitelerinin gerçekleştirdiği ticari faaliyetlere yönelik olumsuz deneyimlerin öğrenilerek, aksayan yönlerin giderilmesi e-ticaret) siteleri tarafindan sunulan hizmetlerin kalite düzeyini yükseltecektir.

\section{Perakende Ticaretten E-Ticarete: E-Ticaretin Tanımı ve Gelişimi}

Ekonomik dünyanın farklı alanlarında internetin kullanımının yaygın hale gelmesiyle beraber toplumdaki insanların hayat kalitesi yükselmiş, tüketicilerin davranışları, alışkanlıkları ve alışveriş biçimleri de dikkate değer bir şekilde değişmiştir. Böylelikle internetin, toplum, kültür, tüketiciler üzerindeki yarattığı etkiler akademik çevre ve uygulayıcılar bakımından gittikçe önemli duruma gelmiştir (Turan, 2008:724). Bilişim çağının hızlı bir ş̧ekilde gelişimi, teknoloji kullanımında hızlı ve yaygın gelişmelere yol açmıştır. Bu gelişim yaşamın bütün alanlarını etkilemesinin yanında tüketicilerin ticaret anlayışlarını ve ticaret şeklillerini de derinden etkilemiştir (Akçi ve Annaç Göv, 2015: 414). İnternette meydana gelen ilerlemeler ile birlikte eticaret sıklıkla kullanılan bir seçenek haline gelmiştir. Bu durumun bir sonucu olarak internetten alışveriş yapan müşteri sayısında ve dünyada e-ticaret siteleri üzerinden yapılan satışlarda dikkate değer bir artış yaşanmaktadır (Akbar ve James, 2014). E-ticaret site hacimlerinin büyümesi, online alışveriş için mobil uygulamaların geliştirilmesi, ödeme ve teslimat seçeneğindeki alternatiflerin artması ile beraber tüm dünyada e-ticaret her geçen gün büyümektedir. Bilişim Sanayicileri TÜBİSAD (Türkiye Bilişim Sanayicileri Derneği) yıllık raporu "Türkiye'de e-ticaret 2019 Pazar Büyüklüğü” verileri incelendiğinde, e-ticaret sektörü 2019 y1lında , \%39 büyüme ile 83,1 milyar liralık hacme ulaşmış durumdayken, 2015-2019 yılları arasında sektörün ortalama yıllık büyüme hızı yüzde 35 civarında olmuştur (TÜBSİAD, 2019).

E-ticaret siteleri tarafından müşterilere sununlan hizmetler; sipariş ile ilgili işlemler, dağıtım, envanter yönetimi, paketleme, müşteri hizmetleri ve gereksinim duyulması durumunda (hasar, iade vb.) tersine lojistik gibi temel lojistik faaliyetleri/süreçleri içerir (Karadeniz ve Işık, 2014). E-ticaret, müşterilere ürünleri online olarak satmaktadır. Dünya Ticaret Örgütü’ne göre eticaret "mal ve hizmetlerin üretim, reklam, satış ve dağıtımlarının telekomünikasyon ağları üzerinden yapılmasıdır". Elektronik ticaret üç aşamadan oluşmaktadır. İlk aşama; reklam ve bilgi araştırmayı kapsayan "satın alma öncesi" aşamadır. İkinci aşama; sipariş verme, satın alma ve ödeme sürecini içinde bulunduran "satın alma" aşamasıdır. Son aşamaysa "siparişin teslim edilmesi" aşamasıdır. Bütün ürün türleri, elektronik ağlar üzerinden tanıtılır, bilgi araştırmas1 yapılır, sipariş işlenir, satın alınır, ödemesi yapılır, teslimatla ilgili lojistik faaliyetler yerine getirilir (Koçak, 2008:20).

E-ticaret hem işletmeler hem de müşterileri açısından önemli avantajlara sahiptir. İşletmeler zamandan ve mekândan bağımsız, çok daha hızlı bir biçimde ticari işlemler yapabilmekte ve bu şekilde maliyet avantajı sağlamaktadır. Tüketicilerse ürün ve hizmetler hakkında daha çok bilgi sahibi olabilmekte ve ürün ve hizmetlere daha uygun fiyatlarla zaman ve mekân sıkıntısı olmadan ulaşabilmektedirler. Bununla beraber tüketiciler istedikleri ürünleri hızlı ve kolay bir şekilde alabilmektedir. Tüketiciler, e-ticaret siteleri sayesinde, birçok ürünü ve çeşidi bir arada bulabilme, ürünü üretenler arasında kısa sürede karşılaştırma yapabilme, indirimlerden yararlanabilme imkânına sahip olmaktadır. Ayrıca, ürünün özelliklerini tüketici, kendisi belirleyebilmektedir. İnternette alışveriş güvenli, ekonomik ve hızlı olduğu için, bu yöntemi tercih eden tüketicilerin sayıları günden güne artmaktadır. $\mathrm{Bu}$ açıdan elektronik ticaret içinde bulunduğumuz bilgi toplumunun hızlı temposu içinde ticari faaliyetlerde bulunmanın en hızlı ve etkili yolu olmaktadır (İzgi, 2018).

Avantajlarının yanında geleneksel ticaret ile karşılaştırıldı̆̆ında e- ticaretin sahip olduğu bazı dezavantajlar da vardır. Tüketicinin satın almış olduğu ürünü dokunmadan yalnızca resimlerini 
inceleyerek sipariş verebilmesi, ürünün kargo şirketince kusurlu bir şekilde teslimatının yapılması, alışveriş yaptıktan sonra sürekli olarak müşterinin e-mail adresine gönderilen bilgilendirme mesajlarının can sıkıcı hale gelmesi, ürünlerle ilgili yaşanan sorunlar olması durumunda ilgili kişilere ulaşılamaması, sipariş verilen ürünün tedarik edilme süresinin uzaması sebebiyle müşterilere geç ulaşması, kargolama işleminin söz verilen süre içerisinde yapılmaması, sipariş verilen ürün ile teslim edilen ürünün farklı olması, ürünün satın alındığı e-ticaret sitesinin iade sürecinin zor olması ya da iadeyi kabul etmemesi, satın alınan ürünün tüketiciye ulaşmamasına rağmen ödemenin yapılmış olması gibi sorunlar e-ticaret sitelerinin dezavantajlarındandır (Gökgül, 2014:85).

Müşteri ihtiyaçlarının belirlenmesi ve anlaşılması e-ticaretin başarısının temelini oluşturur. Müşterilerin değerlendirme ölçütlerinin tanımlanması ve önemsedikleri unsurların belirlenmesi, özel ihtiyaçlarını anlamayı kolaylaştıracak yolları geliştirmek başarı için gereklidir (Broekhuizen ve Huizingh, 2009:440). Bununla beraber e-ticaretin başarısı pazarlanan ürün ve hizmetlerin çeşitlilik arz etmesi ve kaliteli olmasına, ürünün eşsiz olmasına, internet ortamına ve dağıtım kanalının etkinliğine bağlıdır (Enginkaya, 2006:15). Buradaki herhangi bir aksama müşterilerin şikâyet etmelerine sebep olabilmektedir. Üründen ya da verilen hizmetten beklediği performans1 bulamayan, e-ticaret sitesi üzerinden gerçekleştirdiği alışverişin kendisi açısından değer yaratmadığı düşüncesina kapılan müşteri, yaşadığı tatminsizliği şikâyet ederek dile getirebilir (Köse, 2007:36). Özetle, kaliteli hizmetler bekleyen müşteriler çeşitli faaliyetlerden kaynaklanan tatminsizlik yaşarsa şikâyetler ortaya çıkmaya başlayacaktır.

\section{Müşteri Şikâyetleri}

Müşterilerin menuniyet düzeyi ile kendilerine sunulan hizmetten şikâyetçi olma eğilimi arasında bir ilişki vardır. Memnuniyet düzeyi arttıkça müşterilerin şikâyet etme eğiliminin düştüğü, memnuniyet düzeyi düştükçe şikâyet etmeye yönelik eğilimlerinin yükseldiği bilinmektedir (Kozak, 2007: 139-140). Müşterinin memnun olmas1 ya da tam tersi memnuniyetsizlik yaşaması, satın aldığı mal veya hizmetten beklediği performans ile satın alma süreci sonunda görülen gerçek performans arasındaki ilişkiye bağlıdır. Müşterinin beklentisiyle ürünün ya da hizmetin gerçekte sağladığı performans arasında pozitif bir ilişki oluşmuşsa, memnuniyet gerçekleşir, ancak tam tersi bir durumda müş̧eri tatmin olmayacaktır. Müşteri memnuniyeti sağlandığında, marka bağ lılığı oluşacak ve tekrar alımlar gerçekleşecek, tatminsizlik durumundaysa müşterilerce işletmeye karşı negatif davranışlar meydana gelecektir. Müşteriler karşı karşıya kaldıkları olumsuz durumlar sebebiyle şikayet etme davranışında bulunabileceklerdir (Demiray, 2010:50-51). Şikâyet, "satın alınan mal ve hizmetlerin tüketicilerin beklentisini karşılamaması sonucunda ortaya çıkabilen, ya da tüketim sırasında deneyimlenebilecek istenmeyen durumların karşılığıdır" (Kılıç ve Ok, 2012). Diğer bir ifadeyle şikâyet kavramı " müşterilerin, deneyimlediği ürün veya hizmetler hakkında olumsuz geri bildirimde bulunmalarıdır" (Bell vd., 2004:113). Barlow ve Moller (2008)' e göre şikâyet "memnuniyetsizlikten kaynaklanan ve beklentileri karşılanmamış müşterilerin hoşnutsuzluklarını belirtme biçimidir".

Müşteri şikâyetleri, yarattığı doğrudan ve dolaylı maliyetler sebebiyle işletmeler açısından maliyetli olmaktadır. Ancak bu maliyet, şikâyetlerin doğrudan müşterilerin sesi olması sebebiyle işletmeler için çok öenmli bilgi kaynăg olabilir (Kayabaşı, 2010: 28). Müşteri şikâyetleri, işletmelerin sunduğu ürün ve hizmetlerin kalitesini artırabilmek için kritik bir öneme sahiptir. Şikâyetler aracılığıyla müşteri, işletmenin eksikliklerini dile getirmiş olmaktadır. Diğer bir ifadeyle şikâyet davranışı, bir dizi müşteri memnuniyetsizliğinin tepkisidir. Müşterilerin dile getirdikleri bu eksiklikler giderilerek müşteri memnuniyetinin sağlanması gerekmektedir (Özbay ve Sarıca, 2020:863). İyi bir müşteri memnuniyetinin sağlanmas1, müşterilerden gelen şikâyetlerin etkin bir şekilde yönetilmesine bağlıdır. İşletmelerin müşteri şikâyetleri konusunda hiç şikâyet almaması, kusursuz bir hizmet sundukları anlamına gelmemelidir. Aksine bu durum memnun olmayan müşterilerin sessiz kaldıklarını göstermektedir (Heppell, 2006: 151-152). 
Hizmet sunan bir işletmenin, hizmet sunduğu müşterilerinden şikâyet almaları beklendik bir durumu yansitmaktadır (Anderson vd., 2001). Şikâyetler genel olarak olumsuz bir durum gibi görünmesine karşın işletmeler için ürün ya da hizmetteki sorunu bulup, düzeltilmesine firsat verdiği ve bu yolla müşterinin hoşnutsuzluğunu giderme olanağ 1 sağladığ 1 için önem arz etmektedir. Bir işletmenin başarısında etkili olan unsurlardan bir diğeri de, müşteri şikâyetlerini hizmet süreçlerinin iyileştirilmesi ve sorun olduğu düşünülen bölümlerin düzeltilmesinde kullanabilme becerileridir (Zemke ve Anderson, 2007). Bir işletmenin amacının, müşterilerini tatmin edecek ürünler üretmek veya böyle ürünler pazarlamak olduğu dikkate alındığında, müşteri beklentilerini karş1layamamak, işletmenin bir eksikliği olarak düşünülebilir. Müşterilerine etkin bir hizmet vermek isteyen e-ticaret sitelerinin, hizmetlerinin planlanması sürecinde müşteri şikâyetlerini göz önünde bulundurmaları önem arz etmektedir.

\section{E- Ticaret Siteleri ve Online Müşteri Şikâyetleri}

Müşteriler, bir ürün ya da hizmeti satın aldıktan sonra pişmanlık yaşadıklarında, sorunlarına en az gayretle ve genellikle satıcıyla karşı karşıya gelmeden çözüm bulmak isterler. Online şikâyet etme davranışı, algılanan hoşnutsuzluğa hızlı cevap alma olanağı tanıması sebebiyle müşteriler tarafindan tercih edilmektedir (Ndubisi ve Ling, 2006:73). Son yıllarda tüketicilerin internete kolay bir şekilde erişebilmesiyle beraber müşterileri tarafindan yapılan e-şikâyetlerin sayısı da gün geçtikçe artmaktadır. Bu sebeple tüketiciler açısından internet yoluyla yapılan şikâyetler de önem arz etmeye başlamıştır (Goetzinger, 2007).

İnternet ekonomisinde müşteriler her geçen gün daha iyi bilgilenmekte ve beklentileri artmaya devam etmektedir. E-ticaret sitelerinin yükselen satış trafiği geleneksel alışverişten farklı olarak yanında farklı yenilikler ve birçok değişik müşteri profili meydana getirmiştir. Yeni ekonomi kurallarının ve farklı müşteri profillerinin bulunduğu günümüzde online satış yapan girişimcilerin karşı karşıya kaldığ 1 sorunlardan birisi de müşterilerin yaptı̆̆ 1 şikayetlerdir. İnternet üzerinden alışveriş yapan tüketiciler karşılaştıkları problemleri internet ortamında paylaşarak belirttikleri sorunların çözülmesi yönünde geri bildirim sağlamaktadır (Bal, 2014:59). Online yorumlar ile müşteriler, hizmet ya da ürünlerle ilgili deneyimlerine dayalı olarak memnuniyet düzeylerini değerlendirebilmekte, beklentilerini ifade edebilmekte, y1ldız vererek puanlayabilmekte, işletme hakkında yorum yapabilmektedirler (Bilgihan vd., 2018: 604-605).

E-ticaretin üstün yönlerine rağmen, satın alma süreci söz konusu olduğunda, her zaman bir memnuniyetsizlik ve şikâyet söz konusu olabilmektedir. Şikâyetler genel anlamda ürün, hizmet, personel, dağıtım kanalı ve satış sonrası servislerle ilgili beklentilerin karşılanmaması nedeniyle olabilmektedir. Müşteriler, ürünler veya hizmetlere yönelik şikâyetlerini farklı yollarla dile getirmektedir. Müşteriler şikâyetlerini doğrudan işletmeye söyleyebilmekte, yakın çevreleri ile paylaşabilmekte, tüketici derneklerine ya da yasal mercilere bildirebilmektedir (Singh, 1988). Günümüzde internet kullanımının artmasıyla birlikte müşteriler dile getirmek istedikleri şikâyetlerini daha çok dijital ortamlarda ifade etmeye başlamıştır. İnternette yapılan şikâyet etme süreci ve kaynaklarına ilişskin Burucuoğlu ve Erdoğan Yazar (2020) tarafından oluşturulmuş bir şekil aşağıda verilmiştir. 


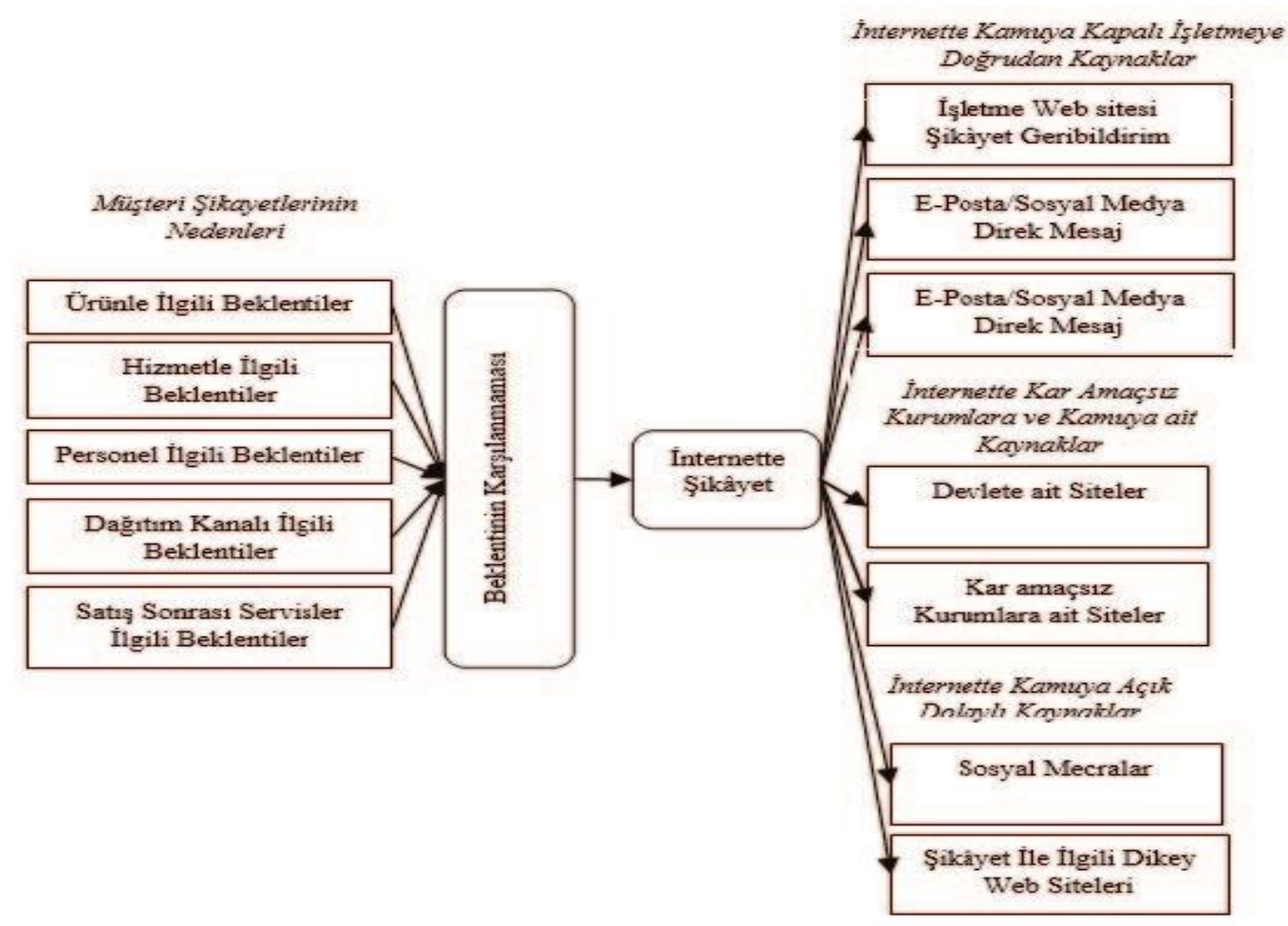

Şekil 1: İnternette Yapılan Şikâyet Etme Süreci ve Kaynakları

Kaynak: (Burucuoğlu ve Erdoğan Yazar, 2020)

Şekil 1' göre internette şikâyetlerin kaynakları kamuya kapalı olarak işletmeye doğrudan yapılan şikâyet başvuruları, internette kamuya açı olarak dolaylı yapılan şikâyet başvuruları ve kamuya yapılan şikâyet başvuruları olmak üzere üç grupta ele alınmıştır. Müşterilerin, işletmenin web sitesinde yer alan iletişim kutucuklarına veya şikâyet geribildirim bölümlerine, işletmenin eposta adreslerine ve sosyal medya hesaplarına şikâyetlerini bildirebilmektedirler. İkinci olarak müşteriler, işletmeler ile ilgili şikâyetlerini internette devlet tarafından ve sivil toplum kuruluşları, dernek ve vakıflar gibi kar amacı gütmeyen sitelere yapabilirler. Turkiye'de Cimer, buna örnek gösterilebilir. Üçüncü olarak müşteriler şikâyet için internet ortamında sosyal ağlar, blog ve forumlar ve yoruma açık her türlü sosyal mecrayı ve/veya şikâyet ile ilgili oluşturulmuş kar amac1 güden veya gütmeyen dikey web sitelerini kullanabilmektedirler (Burucuoğlu ve Erdoğan Yazar, 2020:104). Online tüketiciler karşılaştıkları sorunları genellikle e- şikâyet sitelerinde paylaşarak bunların çözülmesi yönünde geri bildirimde bulunmaktadırlar.

Tüketicilerin işletmelerin mal ve hizmetlerine yönelik şikâyetlerini internet ortamında yer alan şikâyet sitelerinde paylaşmaları kolay, hızlı ve ücretsiz bir yöntem olarak değerlendirilmektedir (Doğru vd., 2014: 34). E-şikâyet siteleri, tüketicilerin şikayelerini kısa bir sürede ve kolaylıkla işletmelere ulaştırmalarını sağlamanın yanısıra işletmelerin ürün veya hizmetteki eksik yönelerini ve hatalarını keşfetmesine yardımcı olmaktadır. Şikâyet eden müşterilerine, interaktif bir şekilde çözüm ve öneriler sunan işletmeler hem müşteri memnuniyeti sağlarlar hem de ürün ve hizmetlerinden yarar görecek potansiyel müşterilerin gözünde olumlu bir imaj oluşturabilirler. Bundan dolayı şikâyetlerin dikkate alınarak analiz edilmesi, başarılı bir pazarlama uygulamasının gerçekleştirilmesi adına önemlidir (İnan ve Özel, 2019:285). 


\section{İlgili Araştırmalar}

Alanyazında farklı çalışmalara konu olan tüketici şikâyet davranışı, internetin yaygınlık kazanmasıyla beraber yeni bir boyut kazanmıştır. Literatürde, şikâyet davranışı ile ilgili çalışmalara sıkça rastlanmaktadır. Ancak, elektronik ortamda paylaşılan şikâyetler ile ilgili çalışmalar son yıllarda artış göstermektedir. Bu çalışmalar, rekreasyon, iletişim, teknoloji, turizm ve sağlıkla birlikte eğitim alanındaki şikayetlere yönelik araştırmaları içermektedir (Argan ve Dursun, 2020:1204). Literatürde şikâyet davranışı ile ilgili araştırmaların sayısı çok olsa da e-ticaret siteleri ile ilgili yapılan çok az sayıda çalışma vardır.

Uzun (2018), "Müşteri Memnuniyeti Sağlamada Müşteri Şikâyetleri Yönetiminin Etkisi: Online Alışverişler Üzerine Bir Araştırma" konulu çalışmasında katılımcıların \%72,7'sinin memnuniyetsizliğinin satın aldığı üründen kaynaklandığını ,\%12,1'inin ise sanal alışveriş mağazası ile ilgili bir memnuniyetsizlik yaşadığını ve \%10,3'ünün kargo hizmetleri ile ilgili memnuniyetsizlik yaşadıkları sonucuna ulaşmıştır.

Kayabaşı (2010) çalışmasında, müşteriler tarafından lojistik faaliyetlere yönelik şikâyetlerinin araştırılmasını amaçlamıştır. İçerik analizi ve anket yoluyla ulaşılan verilerin analizi sonucunda en çok şikâyet edilen konuların ürün şikâyetleri, teslimat şikâyetleri ve ürün iade, değişimi ve ücret iadesi olduğu sonucuna ulaşılmıştır.

Bal (2014) tarafından yapılan araştırmada müşteriler tarafından online satış sitelerine yönelik yapılan şikayetlerin belirlenmesi amaçlanmıştır. Araştırmada Şikayetvar sitesine yapılan yorumlar sonucu ulaşılan veriler analiz edilmiştir. Araştırmanın sonunda tüketici şikâyetlerinin \%60,2'sinin satış süreci ile ilgili olduğu ve bu şikâyetlerin de \% 53,2'sinin ise ürünlerin teslimi ile ilgili sorun yaşayan müşteri şikâyetlerinden oluştuğu sonucuna ulaşılmıştır.

\section{Metodoloji}

Araştırma, yapısı ve süreçleri itibariyle nitel bir araştırmadır. Nitel araştırma, sosyal ya da beşeri bir probleme ilişkin bir birey ya da bir grubun atfettiği anlamları keşfetmeye ve anlamaya yönelik bir yaklaşımdır. Araştırma süreci; soru ve işlem basamaklarının geliştirilmesi, genel anlamda katılımcıların kendi ortamlarından veri toplaması, özel durumlarda genel temalara ulaşılarak tümevarımsal veri analizi yapılması ve araştırmacının verilerin anlamını yorumlama aşamalarını kapsamaktadır (Creswell, 2017:4).

\section{Araştırmanın Amacı ve Önemi}

İnternet teknolojisinde meydana gelen baş döndürücü gelişmeler tüketicileri geleneksel tüketici olmaktan çıkarıp online tüketicilere dönüştürmektedir. İnsanların internetten alışveriş yapması günümüzde çoğu tüketici için farklı ve vazgeçilemez bir satın alma davranış1 oluşturmaktadır. Özellikle Covid-19 döneminde sokağa çıkma yasakları gibi sebepler ve müşterilerin koronavirüs kapma endişesi nedeniyle e-ticareti tercih etme oranları artmış, e-ticaret siteleri talebi karşılamakta zorlanır hale gelmiştir. Bu nedenle yaşanan bazı aksaklıklar müşterilerin şikâyet etmesine sebep olmuştur. Bu şikâyetlerin dikkate alınması ve çözülmesi yoluyla, müşteri memnuniyetinin sağlanarak müşteri sadakatinin kazanılması önemlilik arz etmektedir. Tüm bunlar doğrultusunda bu çalışmanın amacını Covid- 19 pandemik krizi sırasında e-ticaret sitelerine yöneltilen şikâyetlerin incelenmesi oluşturmaktadır. Çalışma sonucunda elde edilen bulguların, eticaret sitelerini kullanan müşterilere ilişkin memnuniyetsizlik kaynaklarını tespit etme ve hizmet sunum planlarını buna göre organize etme bağlamında e-ticaret sitesi yöneticilerine yol göstereceği düşünülmektedir. 


\section{Araştırmanın Yöntemi}

Araştırma Türkiye'de faaliyetlerini sürdüren ve farklı ürün kategorilerinde satış yapan üç eticaret sitesi üzerinde yapılmıştır. Araştırılmak istenen e-ticaret sitelerine ilişkin şikâyetler incelenmiş ve yorumlanmıştır. Araştırma nitel olarak kurgulanmış, veri toplama yöntemi olarak doküman incelemesinden yararlanılmıştır. E-ticaret sitelerinden elde edilen veriler, sikayetvar.com platformundan alınmıştır. Veriler elde edildikten sonra aşağıdaki akışa göre 4 adımda analiz edilmiştir.

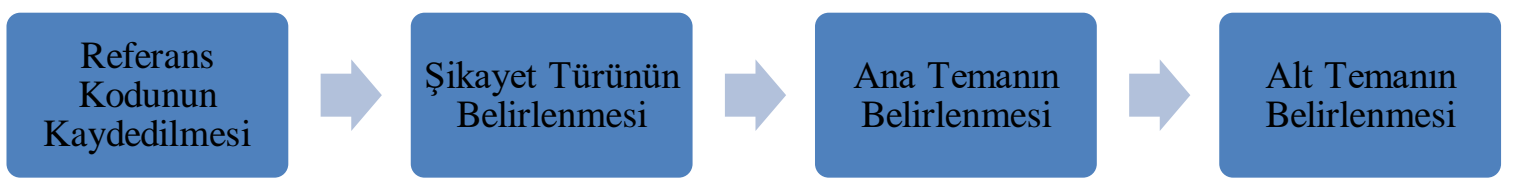

Şekil 2: Veri Toplama Akış Diyagramı

Doküman incelemesi, araştırılmak istenen olgularla ilgili bilgiler içeren yazılı materyallerin analizini kapsar (Özenç ve Özenç, 2013). Dökümanlara, web sayfalarından, haber gruplarından, email, bloglar gibi elektronik formatta da ulaşılabilir (Baş ve Akturan, 2008: 118). Araştırmada toplanan verilerin organize edilmesi ve açıklanan ana tema, kategori ve alt kategorilerin tespitinde içerik analizi tekniğinden faydalanılmıştır. İçerik analizi genellikle araştırmanın önceden belirlenen kategoriler çerçevesinde sistematik bir şekilde değerlendirilmesini sağlayan bir araştırma yöntemidir (Geray, 2004: 133). Diğer bir ifadeyle içerik analizi, incelen bir metindeki değişkenleri ölçmeyi amaçlayan, sistematik ve nesnel bir şekilde sayısal olarak yapılan analiz yöntemidir (Wimmer ve Dominick, 2000:135-136). Bu süreçte yapılan temel işlem, birbirine benzediği düşünülen verileri belli kavram ve temalar odağında bir araya toplamak ve bu kavram ve temaları okuyucunun anlayacağı şekilde düzenleyerek yorum yapmaktır (Yıldırım ve Şimşek, 2011: 227). İçerik analizi sürecinde mesaj değeri taşıyan her türlü veri belirli bir amaç doğrultusunda taranır, kategorilere (temalara) ayrılır, özetlenir ve bulgular araştırma amaçları doğrultusunda analiz edilip yorumlanır (Şahin Başfırıncı, 2008:53).

\section{Araştırmanın Kapsamı ve Sınırlıklıkları}

Araştırmanın kapsamını şikâyetlerin Türkiye'de Covid-19 salgını döneminde olmasını sağlamak amaciyla, 2 Haziran 2020 tarihini temel alarak bu tarihten geriye doğru her e-ticaret sitesi için çözüme ulaştırılmamış 100 şikâyet oluşturmaktadır. Dolayısıyla araştırma bağlamında Türkiye'de faaliyetlerini sürdüren farklı ürün kategorilerinde satış yapan N11, Gittigidiyor ve Hepsiburada e-ticaret şirketlerine yönelik yapılan toplam 300 şikâyet analiz edilmiştir. Şikâyetler belirlenirken Türkiye'de ilk koronavirüs vakasının görüldüğü tarihten sonra yapılmış olmasına özellikle dikkat edilmiştir.

Çalışma kapsamındaki verilerin yalnızca Türkiye'nin ilk çevrimiçi şikâyet sitesi olarak bilinen sikayetvar.com portalı üzerinden toplanması, yapılan şikâyetlerin doğru olduğunun varsayılması çalışmanın en önemli sınırlılıklarını teşkil etmektedir. Bulguların yalnızca araştırmanın yapıldığı zaman aralığını yansıtması çalışmanın bir diğer önemli sınırlığını oluşturmaktadır.

\section{Kodlama Sistemi ve Analiz}

Elde edilen veriler MAXQDA nitel araştırma programı aracılı̆̆ 1 ile analiz edilmiştir. $\mathrm{Bu}$ aşamada şikâyet metinleri analiz edilmiş, her şikâyet için kodlama yapılmış ve veriler kategorik hale getirilmiştir. Kategoriler oluşturulurken şikâyet konuları göz önünde bulundurularak kodlamalar yapılmıştır. Bu aşamada şikâyet metinleri temel alınarak kodlama türü geliştirilmiştir (Creswell, 2017). Bu kodlama neticesinde şikâyetler tek tek incelenerek temalandırılmış; temalandırma işlemi ve alt tema oluşturulma süreci başlatılmış; birden fazla ana ve alt temalara 
ayrılmıştır. Sonuçta 5 ana tema ve 23 alt tema oluşturulmuştur. Oluşturulan ana temalar ve alt temalar Tablo 1'de gösterilmiştir.

Tablo 1: Şikâyetlerle İlgili Ana ve Alt Temalar

\begin{tabular}{|c|c|}
\hline ANA TEMALAR & ALT TEMALAR \\
\hline Ürün ile İlgili Şikâyetler & $\begin{array}{ll}\text { - } & \text { Orijinal olmayan ürün } \\
\text { - Urün ile ilgili hatalı bilgi verilmesi } \\
\text { - } & \text { Kullanılmış ürün } \\
\text { - } & \text { Arıalı//Kırı ürün } \\
\text { - } & \text { Yanlış ürün } \\
\text { - } & \text { Eksik ürün } \\
& \text { Ayılı ürün } \\
\end{array}$ \\
\hline Sipariş Süreci ile İlgili Şikâyetler & $\begin{array}{ll}\text { - } & \text { Kupon/Hediye çeki/Puan kullanımı } \\
\text { - } & \text { Stokta olmayan ürünlerin satışta olması } \\
\text { - } & \text { Müşteri bilgisi olmadan sipariş iptali } \\
\text { - } & \text { Siparişin takibi ile ilgili sorunlar } \\
\text { - } & \text { Sipariş ile ilgili fatura verilmemesi } \\
\end{array}$ \\
\hline Teslimat Süreci ile İlgili Şikâyetler & $\begin{array}{ll}\text { - } & \text { Haksız kargo ücreti alınması } \\
\text { - } & \text { Yanlış adrese gönderim yapılması } \\
\text { - } & \text { Siparişlerin ulaşmaması } \\
\text { - Urünün kargoya zamanında verilmemesi }\end{array}$ \\
\hline $\begin{array}{c}\text { Müşteri Hizmetleri/ Canlı Destek ile İlgili } \\
\text { Şikâyetler }\end{array}$ & $\begin{array}{ll}\text { - } & \text { Müşteri hizmetleri/ canlı desteğin kaba davranışları } \\
\text { - } & \text { Şikâyetlere ilişkin yeterli çözümün sunulmaması } \\
\text { - İletilen mesajlara cevap alamama(Mail/canlı destek) } \\
\text { - } \quad \text { İletişim kurulacak birimlere ulaşamama } \\
\text { - } \quad \text { Satış yapıllan mağazanın ilgisizliği }\end{array}$ \\
\hline İade Süreci ile İlgili Şikâyetler & $\begin{array}{ll}\text { - } & \text { İade isteğinin reddi } \\
\text { - } & \text { Ücret iadesinin yapılmaması }\end{array}$ \\
\hline
\end{tabular}

\section{Geçerlik ve Güvenirlik}

Nitel araştırmaların geçerliği ve güvenirliği, araştırmacıların ulaştığı kayıtlarla veya yaptığı yorumlarla, gerçek hayattaki grubun, kişinin veya kurumun gerçeklerinin örtüşme derecesine bağlıdır. Kayıtlar ve yorumlar gerçeğine uygun olduğu ölçüde geçerli sayılır ve sınamalarda aynı çıktığı ölçüde güvenilirdir (Karagöz, 2017: 604). Sonuçların inandırııılığı bilimsel bir araştırmanın kritik ölçütlerinden biridir. İnandırıcılık, geçerlik ve güvenirlik araştırmalarda en çok kullanılan kriterdir. Nitel araştırmalarda geçerlik, tutarlılık ile sağlanmaktadır. Tutarlılık ise, temaların altında yer alan verilerin anlamlı bir bütün oluşturması ve bu temaların bütününün araştırmayla ulaşılan verileri anlamlı olarak açıklayabilmesi ile ilişkilidir (Yıldırım ve Şimşek, 2016: 250). Araştırmada belirlenmiş olan temalardan farklı bir veri olmadığı ve ulaşılan veriler kapsamı etkin bir şekilde temsil edildiği için araştırma tutarlık göstermektedir. Araştırmanın geçerliliğinde yoğun ve uzun dönemli ilgililik önemli bir konudur (Argan ve Dursun, 2020: 1205). Bu çalışmada araştırmacı uzun dönemli şikâyet konularıyla ilgilenmiş ve kodlama sürecinde tekrar tekrar şikâyetler gözden geçirmiştir. Çalışmanın geçerliliğini desteklemek için farklı kaynaklardan kanıtlara ulaşılmıştır. Gözden geçirilen kaynaklardaki şikâyetlerin araştırmadaki şikâyetlerle benzerlik gösterdiği gözlemlenmiştir. Çalışmanın tamamını incelemek için bir dış denetleyici kullanmak nitel bir araştırmanın geçerliğini kuvvetlendirir. Bir çalışmada betimlemenin doğruluğu, araştırma soruları ve veriler arasındaki ilişkiler, ham verilerin yorumlanması veya verilerin analizleri ile ilgili süreçlerin incelenmesi için bağımsız bir araştırmacını sürece dâhil edilmesi nitel bir çalışmanın tamamının geçerliğini artırmaktadır (Creswell, 2017: 202-203). Bu çalı̧̧mada alanında yetkin iki 
uzmandan çalışmanın süreçleri hakkında bilgi alınmıştır. Bu sayede araştırmanın geçerliğine katkıda bulunulmuştur.

\section{Bulgular}

Belirlenen şikâyet kategori (temalarına) göre toplamda 300 şikâyet incelenmiştir. Müşterilerin kullandığı, sık tekrarlanan olumsuz kelimeler, ifadeler ve vurgular analiz edilmiştir. Bazı müşterilerin şikâyetleri tek bir ana ve alt temaya ilişkinken, bazı müşterilerin şikâyetleri birden fazla ana temaya ve alt temaya yönelik olmuştur. MAXQDA programı aracılığı ile üç işletme ile ilgili kodlamaların genel görünümü Tablo 2'de gösterilmektedir.

Tablo 2: Şikâyetlerin Genel Görünümü

\begin{tabular}{|c|c|c|c|c|}
\hline Kod Sistemi & Gittigidiyor & Hepsiburada & N11 & Toplam \\
\hline \multicolumn{5}{|l|}{ Ürün ile İlgili Şikâyetler } \\
\hline Orijinal olmayan ürün & 3 & 1 & 5 & 9 \\
\hline Ürün ile ilgili hatalı bilgi verilmesi & 1 & 3 & 4 & 8 \\
\hline Kullanılmış ürün & 1 & 0 & 2 & 3 \\
\hline Arızalı/Kırık ürün & 8 & 8 & 10 & 26 \\
\hline Yanlış ürün & 4 & 8 & 9 & 21 \\
\hline Eksik ürün & 2 & 14 & 4 & 20 \\
\hline Ayıplı ürün & 10 & 5 & 4 & 19 \\
\hline \multicolumn{5}{|l|}{ Sipariş Süreci ile İlgili Şikâyetler } \\
\hline Kupon/Hediye çeki/Puan kullanımı & 7 & 0 & 1 & 8 \\
\hline Stokta olmayan ürünlerin satışta olması & 5 & 2 & 5 & 12 \\
\hline Müşteri bilgisi olmadan sipariş iptali & 6 & 6 & 5 & 17 \\
\hline Siparişin takibi ile ilgili sorunlar & 5 & 1 & 2 & 8 \\
\hline Sipariş ile ilgili fatura verilmemesi & 5 & 1 & 4 & 10 \\
\hline \multicolumn{5}{|l|}{ Teslimat Süreci ile İlgili Şikâyetler } \\
\hline Haksız kargo ücreti alınması & 4 & 1 & 5 & 10 \\
\hline Yanlış adrese gönderim yapılması & 1 & 2 & 5 & 8 \\
\hline Siparişlerin ulaşmaması & 28 & 16 & 18 & 62 \\
\hline Ürünün kargoya zamanında verilmemesi & 19 & 33 & 15 & 67 \\
\hline \multicolumn{5}{|l|}{$\begin{array}{l}\text { Müssteri Hizmetleri/Canlı Destek ile İlgili } \\
\text { Şikâyetler }\end{array}$} \\
\hline Müşteri hizmetleri/ canlı desteğin kaba davranışları & 0 & 4 & 5 & 9 \\
\hline Şikâyetlere ilişkin yeterli çözümün sunulmaması & 15 & 23 & 30 & 68 \\
\hline $\begin{array}{l}\text { İletilen mesajlara cevap alamama(Mail/canlı } \\
\text { destek) }\end{array}$ & 3 & 7 & 3 & 13 \\
\hline İletişim kurulacak birimlere ulaşamama & 17 & 31 & 17 & 65 \\
\hline Satış yapılan mağazanın ilgisizliği & 9 & 5 & 9 & 23 \\
\hline \multicolumn{5}{|l|}{ İade Süreci ile İlgili Şikâyetler } \\
\hline İade isteğinin reddi & 5 & 10 & 20 & 35 \\
\hline Ücret iadesinin yapilmaması & 13 & 7 & 11 & 31 \\
\hline TOPLAM & 171 & 188 & 193 & 552 \\
\hline
\end{tabular}

Tablo 2 incelendiğinde e-ticaret sitelerine gelen şikâyetler ana temalar açısından değerlendirildiğinde, müşterilerin sırasıyla en fazla sorun yaşadığı ana temaların müşteri hizmetleri/canlı destek ve teslimat süreci ile ilgili şikâyetler olduğu görülürken, en az şikâyet edilen ana tema ise sipariş süreci olmuştur. 
Tabloya göre ürün ile ilgili şikâyetler ana teması incelendiğinde müşterilerin şikâyetlerinin en çok yoğunlaştığı alt temanın arızalı veya kırık ürün gönderilmesi olduğu görülmüştür. En az şikâyetin görüldüğ̈̈ alt tema ise kullanılmış üründür. Sipariş süreci ile ilgili şikâyetler ana temasında müşterilerin en fazla şikâyet ettiği konu müşteri bilgisi olmadan siparişlerin iptal edilmesiyken; kupon, hediye çeki ve puan kullanımı ve siparişlerin takibi ile ilgili sorunlar bu temada en az şikâyetin yaşandığı konulardır. Teslimat süreci ile ilgili şikâyetlerde en fazla şikâyet alan alt temalar siparişlerin kargoya verilmemesi ve siparişlerin ulaşmaması olarak belirlenmişken, bu ana tema içerisinde en az şikâyet ise yanlış adrese gönderim yapılması olmuştur. Müşteri hizmetleri/canlı destek ile ilgili şikâyetler ana temasında, sırasıyla şikâyetlere ilişkin yeterli çözümün sunulmaması ve iletişim kurulacak birimlere ulaşamama en çok şikâyet alan alt temalar olurken, müşteri hizmetleri/ canlı desteğin kaba davranışları en az şikâyeti almıştır. İade süreci ile ilgili şikâyetler ana temasında iade isteğinin reddi ve ücret iadesinin yapılmaması benzer yoğunlukta müşteri şikâyeti almıştır.

E-ticaret sitelerinin toplam şikâyet bazında aralarında büyük farklılıklar olmamasına rağmen en fazla şikâyeti alan N11 olurken en az şikâyet alan e-ticaret sitesi Gittigidiyor olmuştur. MAXQDA programıla yapılan analizler sonucunda Kod Matris Tarayıcısı verileri elde edilmiştir. Kod Matris Tarayıcısındaki veriler sayesinde katılıme firmalar arasında kıyaslama yapılabilmektedir. Araştırma kapsamında incelen üç firma ile ilgili karşılaştırma yapabilmek için oluşturulan şekil aşağıda verilmiştir.

Şekil 3: E-ticaret Sitelerine Yönelik Kod Matris Tarayıcısı

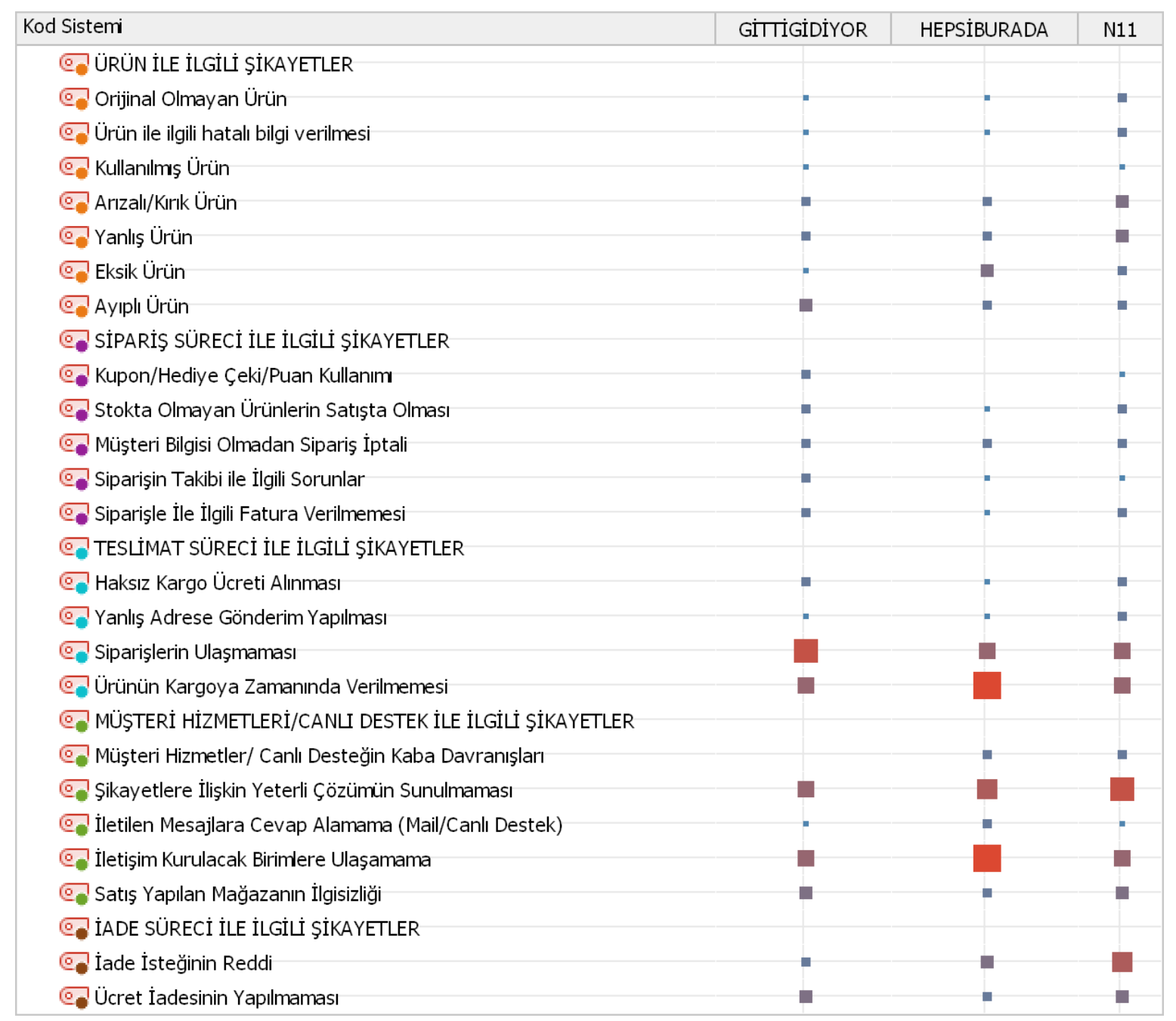

Turkish Studies, 15(4) 
Kod matris tarayıcısında sütunlar farklı belgeleri listeler, alt temalarla, belgeler arasındaki oluşan karelerin büyüklüğü ilgili belgede o kodun geçme yoğunluğunu gösterir. Karenin büyüklüğü arttıkça kodun ilgili belgede daha fazla geçtiği söylenebilir. Bu doğrultuda Şekil 3 yorumlandığında Gittigidiyor e-ticaret sitesi ile ilgili en fazla şikâyet alan kategori siparişlerin ulaşmaması iken, Hepsiburada e-ticaret sitesi ile ilgili olarak ürünün kargoya zamanında verilmemesi ve iletişim kurulacak birimlere ulaşılmaması en fazla şikâyet edilken konudur. N11'de ise şikâyetlere ilişkin yeterli çözüm yolunun sunulmamasının müşteriler tarafından en çok şikâyet edilen konu olduğu söylenebilir. Üç e-ticaret sitesi ile ilgili ortak olarak ortaya çıkan şikâyetler siparişlerin ulaşmaması, ürünün kargoya zamanında verilmemesi, şikâyetlere yeterli çözüm bulunamaması ve iade isteklerinin reddedilmesi olarak belirlenmiştir.

Her bir e-ticaret sitesine ilişkin ana temaların altında yer alan alt kodlar bazında yapılan şikâyetlerin analiz edilmesinde ise Tek Vaka Modelinden ve kod bulutlarından yararlanılmıştır. Tek Vaka Modeli; seçilen belgenin notlarını, kodlarını kod bölümlerini görünür kılmayı amaçlar. Belge ile kodlar çizgilerle birbirine bağlanmıştır ve her bir çizginin genişliği birbirinden farklıdır. Genişlik her bir kodun önemine işaret etmektedir. Kod bulutu; alt kodların sıklıklarına göre oluşturulmakta ve en sık tekrar edenler kalın ve ön planda olacak şekilde haritada yer almaktadır (www.maxqda.com). Gittidiyor firmasına yönelik şikâyetlerin analizi sonucunda oluşturulan Tek vaka modeli aşağıda verilmiştir.

\section{Tek-Vaka Modeli}

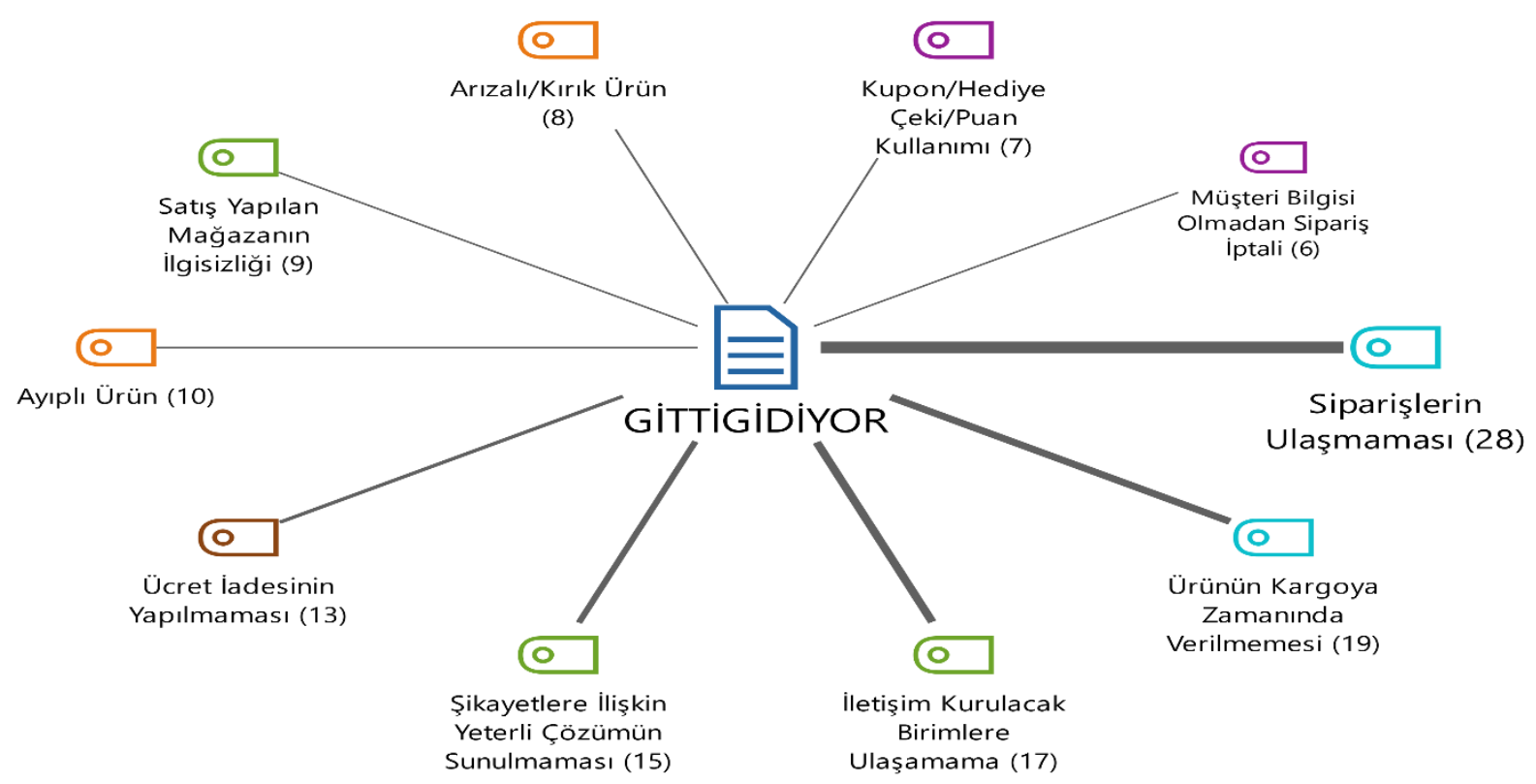

Şekil 4: Gittigidiyor Tek Vaka Modeli

Gittigidiyor firmasına yönelik olarak yapılan şikayetler analiz edilerek oluşturulan kod bulutu Şekil 5'de gösterilmiştir. 


\section{Urínin Kargoya Zamanmola Verilmemesi \\ Ũeret ladesinin Yapulmaması \\ Siparisle Ile ilgill Fatura Verilmemesi \\ Kupon/Hedīye Geki/Puan Kullamum \\ Mișteri Bilgisisi Olmadlan Sipariș Iptali Eksı ürun \\ Siparişin Takilhi ille ilgili Sorunlar Avum| Ürín \\ Siparişlerin Ulaşmamas

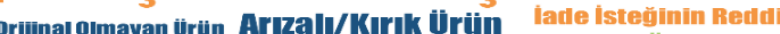 \\ Stokta Olmayan Urïnlerin Satıșta OJması Haksız Kargo Ücreti Almması Yanlıș Ürïn

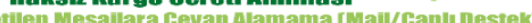 \\ Satuş Yapulan Mağazann IIIgisizinị̆ \\ Şikayetlere ilişkin Yeterli ţöziimuin Sunulmaması \\ Iletişim Kurulacak Birimlere Ulaşamama}

Şekil 5: Gittigidiyor Kod Bulutu

Gittigidiyor e-ticaret sitesine yönelik tek vaka modeli ve kod bulutu incelendiğinde firma ile ilgili en çok şikâyet alan alt temaların sırasıyla siparişlerin ulaşmaması, ürünün kargoya zamanında verilmemesi, iletişim kurulacak birimlere ulaşamama ve şikâyetlere ilişkin yeterli çözümün sunulamaması olarak görülmüştür.

Hepsiburada firmasına yönelik şikâyetlerin analizi sonucunda oluşturulan Tek Vaka Modeli aşağıda verilmiştir.

\section{Tek-Vaka Modeli}

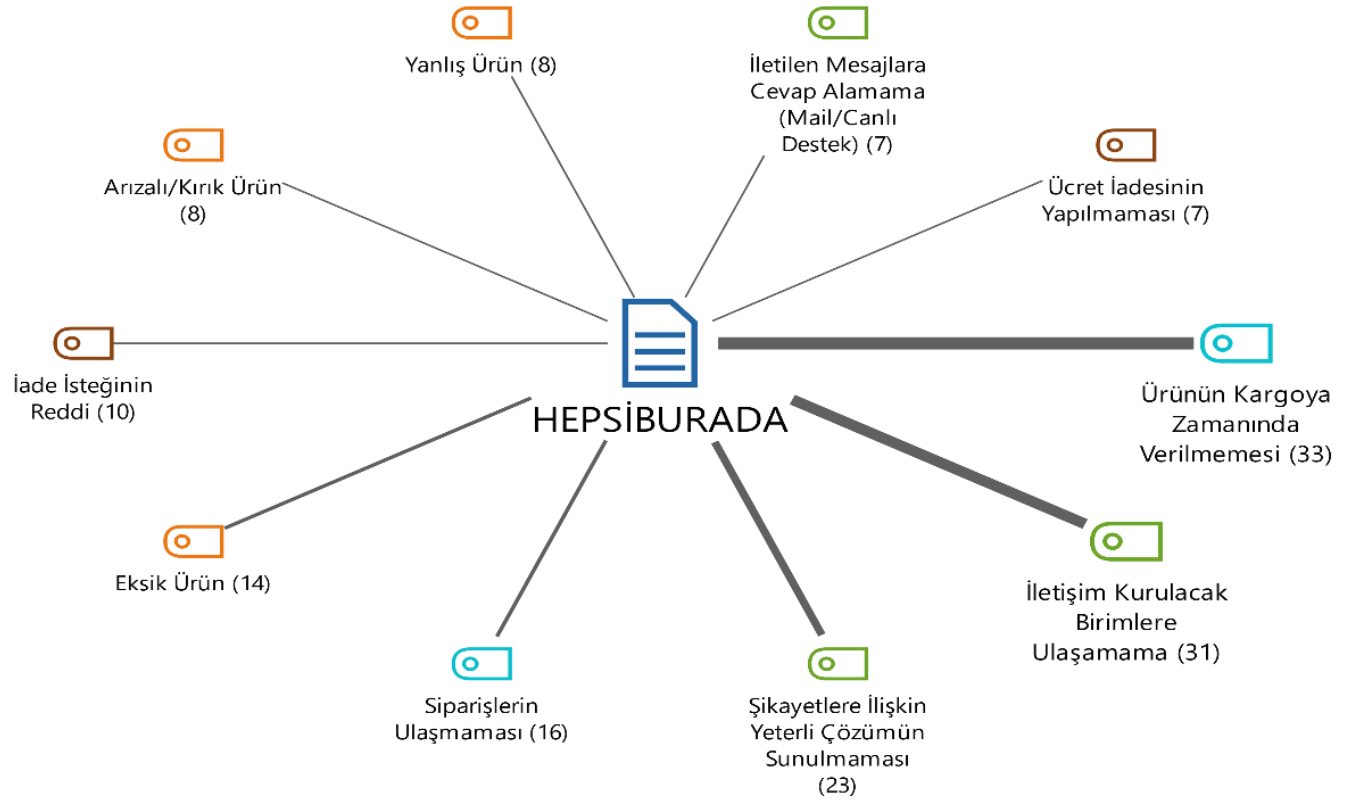

Şekil 6: Hepsiburada Tek Vaka Modeli

Hepsiburada firmasına yönelik olarak yapılan şikâyetler analiz edilerek oluşturulan kod bulutu Şekil 7'de gösterilmiştir. 


\section{Şikayetlere iliş̧kin Yeterli Çöziimuin Sunulmaması \\ Satıș Yapulan Mağazanun ilgisizliği Ürün ile ilgili hatalı bilgi verilmesi

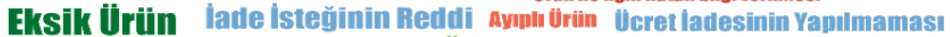

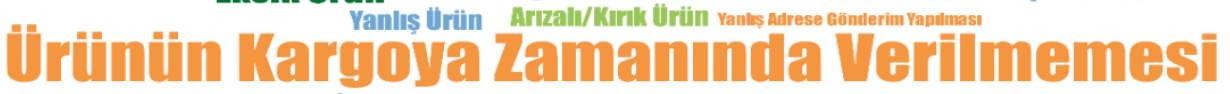 Iletilen Mesajlara Gevap Alamama [Mail/Ganlı Destek] \\ stokta otmayan ürümerin saușta otması Siparişlerin Ulaşmaması \\ Muişteri Bilgisi Olmadlan Sipariş Iptali \\ Illetișịm Kưrulacak Birimlere Ulaşamama}

Şekil 7: Hepsiburada Kod Bulutu

Hepsiburada e-ticaret sitesine yönelik tek vaka modeli ve kod bulutu incelendiğinde firma ile ilgili en çok şikâyet alan alt temaların sırasıyla ürünün kargoya zamanında verilmemesi, iletişim kurulacak birimlere ulaşamama, şikâyetlere ilişkin yeterli çözümün sunulamaması ve siparişlerin ulaşmaması olarak görülmüştür. verilmiştir.

N11 firmasına yönelik şikâyetlerin analizi sonucunda oluşturulan Tek Vaka modeli aşağıda

\section{Tek-Vaka Modeli}

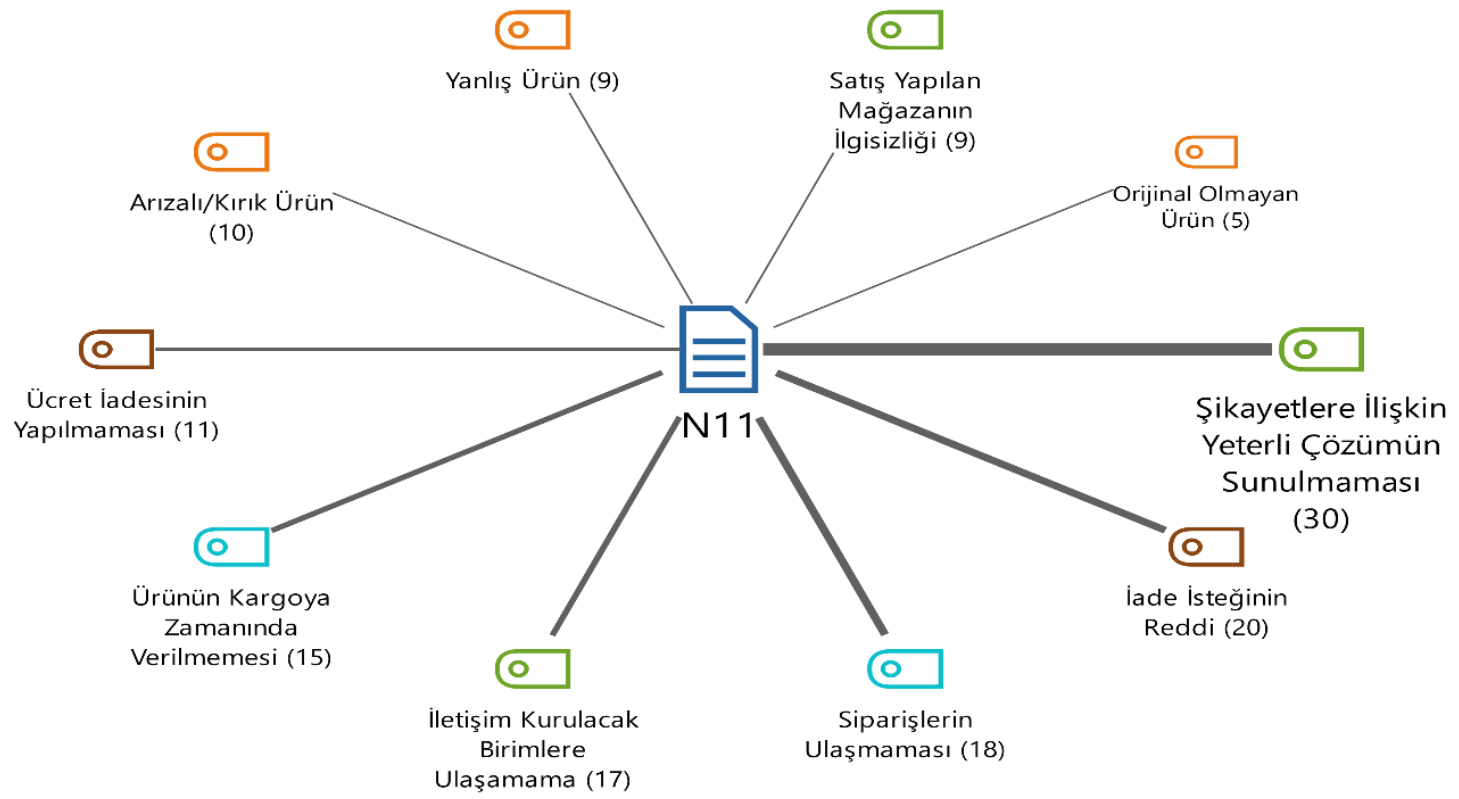

Şekil 8: N11 Tek Vaka Modeli

N11 firmasına yönelik olarak yapılan şikâyetler analiz edilerek oluşturulan kod bulutu Şekil 9'da gösterilmiştir. 


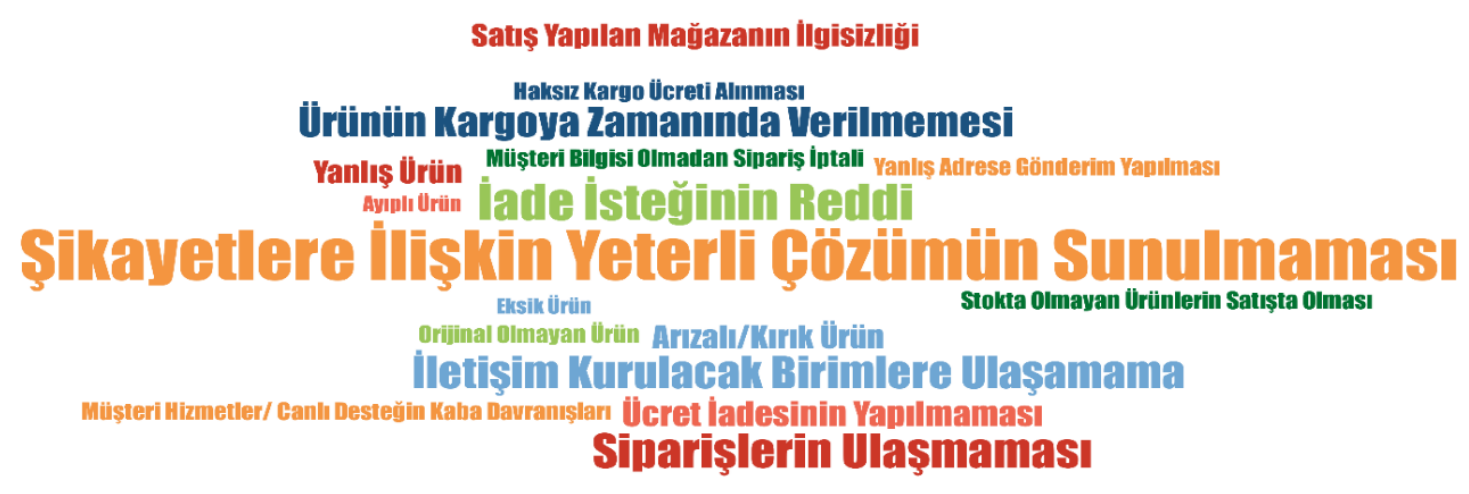

Şekil 9: N11 Kod Bulutu

N11 e-ticaret sitesine yönelik tek vaka modeli ve kod bulutu incelendiğinde firma ile ilgili en çok şikâyet alan alt temaların sırasıyla, şikâyetlere ilişkin yeterli çözümün sunulamaması, iade isteğinin reddi, siparişlerin ulaşmaması, iletişim kurulacak birimlere ulaşılamaması ve ürünün kargoya zamanında verilmemesi olarak görülmüştür.

\section{Sonuç, Tartışma ve Öneriler}

Günümüzde müşteri şikâyetlerinin çözüme kavuşturulması e-ticaret siteleri için oldukça önemli bir durum halini almaya başlamıştır. E-ticaret sitelerinin gelirlerini artırmalarının yanında müşterileri tarafından devamlı olarak tercih edilmelerinin arkasında, müşterilerin verilen hizmetlerden memnuniyet duymaları ve etkin bir şikâyet yönetimi bulunmaktadır.

Koronavirüsün dünyayı etkisi altına almasından sonra ülkelerin çoğu salgının yayılmaması için birçok tedbir almıştır. Sokağa çıkma yasakları ve insanların hastalık kapma endişesi gibi nedenlerle perakende sektörü zayıflasa da e-ticaret altın dönemini yaşamaya başlamıştır. $\mathrm{Bu}$ noktada koronavirüs salgını e-ticaret yapan firmalar için hizmetlerini doğru bir şekilde yönettikleri takdirde gelirlerini arttırmaya yönelik bir firsat yaratmıştır. Çünkü bu süreç içerisinde evlerinde kalan insanların büyük bölümü ailelerini ve kendilerini koronavirüs tehlikesinden korumak için market ihtiyaçları dâhil olmak üzere kıyafet, mobilya, kozmetik gibi alışverişlerini internet üzerinden gerçekleştirmeye başlamışladır. Ancak e-ticaret siteleri artan talebi karşılamakta zorlanmışlardır. E-ticaret sitelerinden alışveriş yapan müşterilerin almış olduğu hizmetten memnun kalmamas1 ve beklentilerinin karşılanmaması sonucunda müşteri şikâyetlerinde artış yaşanması kaçınılmaz hale gelmiştir. Bu doğrultuda bu araştırmada Covid- 19 pandemik krizi sırasında eticaret sitelerine yöneltilen şikâyetleri incelenmiştir. Çalışma, tüketicilerin şikâyetlerini paylaştı̆ğ, Türkiye'nin önde gelen platformlarından biri olan sikayetvar. com'da yayınlanan şikâyetlerin içerik analizi ile gerçekleştirilmiştir.

Araştırmada e-ticaret sitelerine gelen şikâyetler ana temalar açısından değerlendirildiğinde müşterilerin sırasıyla en fazla sorun yaşadığı ana temaların müşteri hizmetleri/canlı destek ve teslimat süreci ile ilgili şikâyetler olduğu görülürken, en az şikâyet edilen ana temanın ise sipariş süreci olduğu görülmüştür. Kayabaşı (2010) ve Bal (2014) tarafindan yapılan araştırmalarda da müşterilerin en çok şikâyet ettiği konuların başında ürün teslimi olduğu görülmüştür. Bununla birlikte Yanar Gürce ve Tosun (2017) tarafindan kargo hizmetlerine yönelik müşteri şikayetlerinin analiz edilmesinin amaçlandığı araştırmada müşteriler tarafından en çok şikayet edilen konuların hizmetlerin zamanında söz verildiği gibi gerçekleşmemesi ve ürün ve hizmetlerin zamanında müşterilere teslim edilememesi olduğu görülmüştür. Araştırmamızda bu sonuçların oluşmasında salgın döneminde e-ticarete yönelimin artması ve bu artış sebebiyle ürün tedarik sürecinde gecikmeler yaşanması nedeniyle ürünlerin kargoya geç verilmesinin sebep olduğu söylenebilir. Ayrıca kargo şirketlerinin yoğun olması nedeniyle kargoların teslimatında yaşanan gecikmelerin bu şikâyetlerin alınmasında önemli bir payı vardır. E-ticaret şirketlerinin bu alanlarda koordineli 
olarak gelişmesi, lojistiği sağlayan şirketlerle olan iletişimin canlı tutulması şikâyet yoğunluğunu düşürebilir. Ayrıca çalışanların müşteri hizmetleri ile ilgili yaşadıkları sorunları azaltnak için müşteri temsilcileri/canlı destekte çalışan kişi sayısının artırılması ve bu bölümde çalışan temsilcilere daha geniş yetkilerin verilmesi şikâyetlerin azalmasında bununla beraber müşteri memnuniyetinin artırılmasında önemli bir payı olabilir. Çünkü e-ticaret şirketlerinin yöneticileri müşteri memnuniyetsizliklerinin nedenlerini öğrenerek, müşterileri memnun etme yolunda çeşitli faaliyetlerde ve müşteriyi odağa alan düzenlemelerde bulunmak zorundadır.

E-ticaret işletmeleri ayrı ayrı incelendiğinde Gittigidiyor e-ticaret sitesi ile ilgili en fazla şikâyet alan konu siparişlerin ulaşmaması iken, Hepsiburada e-ticaret sitesi ile ilgili olarak ürünün kargoya zamanında verilmemesi ve iletişim kurulacak birimlere ulaşılmaması en fazla şikâyet edilen konudur. N11'de ise şikâyetlere ilişkin yeterli çözüm yolunun sunulmaması müşterilerin en fazla yakındığı konudur. Üç e-ticaret sitesi ile ilgili ortak olarak ortaya çıkan şikâyetler siparişlerin ulaşmaması, ürünün kargoya zamanında verilmemesi, şikâyetlere yeterli çözüm bulunamaması ve iade isteklerinin reddedilmesi olarak belirlenmiştir. Özellikle salgın döneminde yoğunluk kaynaklı olarak aynı gün kargo güvencesinin verilmesinden kaçınmaları ve kargo sürelerini belirtirken kargo firmasının kota miktarını düşünerek daha geniş zaman dilimleri belirlemeleri daha uygun olacaktır. Çünkü işletme ürünü zamanında tedarik edip kargoya vermeye çalışsa da kargo şirketlerinin kota uygulaması nedeniyle ürünlerin yola çıkması gecikmekte, bu da işletmenin hak etmese de şikâyet almasina sebep olacaktır.

Genel anlamda değerlendirildiğinde, e-ticaret sitesi yöneticilerileri müşteri memnuniyetsizliklerinin nedenlerini öğrenmeli, müşteriyi memnun etme yolunda farkl1 faaliyetlerde ve müşteriyi odağa alan düzenlemelerde bulumalıdır. Müşteri şikâyetleri başarısız hizmetleri çözüme ulaştırabilmek adına değerli bilgi kaynağı olarak görülmeli, tüketicinin e-ticaret sitesine şikâyet ile geldiği o an işletmenin yapması gereken en önemli şeyin mazeret üretmek yerine şikâyet sahibi tüketiciyi dinlemek ve sorunu derinlemesine anlamak olduğu bilinmelidir.

Bu çalışmada Türkiye'de faaliyet gösteren üç e-ticaret sitesine Covid-19 salgını sürecinde yapılan şikâyetlerin analizi yapılmıştır. İleride yapılacak çalışmalarda farklı e-ticaret sitelerinin eklenmesiyle daha kapsamlı çalışmalar yapılabilir. Ayrıca salgın öncesi dönemlerde yapılan şikâyetlerle salgın dönemindeki şikâyetlerin karşılaştırılması yapılarak dönemler arasındaki farklılaşmalar belirlenebilir.

\section{Kaynakça}

Akbar, S. ve James, P.T.J. (2014). Consumers' attitude towards online shopping: Factors influencing employees of crazy domains to shop online. Journal of Management and Marketing Research, 14 (1), 1-11.

Akçi, Y. \& Annaç Göv, S. (2016). Tüketicilerin E-Ticaret Algılarının İncelenmesi (Gaziantep ve Adıyaman Örneği). Mehmet Akif Ersoy Üniversitesi Sosyal Bilimler Enstitüsü Dergisi, 1 (13), 413-433. https://doi.org/10.20875/makusobed.440607

Anderson K., Allan D. \& Finucane P. (2001) A 30-Month Study of Patient Complaints at a Major Australian Hospital. Journal of Quality in Clinical Practice 21, 109-111. https://doi.org/10.1046/j.1440-1762.2001.00422.x

Argan, M. T. ve Dursun, M. T. (2020). Şikâyetin Ödüldür Bize: Etkinlik Bilet Dağıtımı ve Biletix Şikâyetleri. Türk Turizm Araştırmaları Dergisi, 4(2), 1199-1215. https://doi.org/10.26677/tr1010.2020.390

Bal, V. (2014). Online Satış Girişimcilerinin Karşılaştıkları Müşteri Şikâyetlerinin Analizi. AİB̈̈ Sosyal Bilimler Enstitüsü Dergisi, Cilt:14 (1), 59-74. https://doi.org/10.11616/abantsbe.476 
Barlow, J. \& Moller, C. (2008). A Complaint is a Gift: Recovering Customer Loyalty When Things Go Wrong, Published by Berrett-Koehler Publishers.

Baş T. \& Akturan U. (2008). Nitel Araştırma Yöntemleri NVivo 7.0 ile Nitel Veri Analizi. Seçkin Yayıncilik.

Bell, S. J., Mengüç, B. \& Stefani, S. L. (2004). When Customers Dissappoint: A Model of Relational İnternal Marketing and Customer Complaints. Journal of the Academy of Marketing Science, 32(2), 112-126. https://doi.org/10.1177/0092070303261467

Bilgihan, A., Seo, S. \& Choi, J. (2018) Identifying Restaurant Satisfiers and Dissatisfiers: Suggestions from Online Reviews, Journal Of Hospitality Marketing \& Management 27(5), 601-625, https://doi.org/10.1080/19368623.2018.1396275

Broekhuizen, T.\& Huizingh, E.K.R.E. (2009). Çevrimiçi satın alma belirleyicileri: Etkileri doğrudan deneyim tarafindan denetleniyor mu?, Management Research News , 32 (5), 440-457. https://doi.org/10.1108/01409170910952949

Burucuoğlu, M. \& Erdoğan Yazar, E.(2020). Üçüncü Parti Platformda Kargo Firmalarına Yapılan Müşteri Şikâyetlerinin İçerik Analizi. Ekonomik ve Sosyal Araştırmalar Dergisi, 16(1). 99114.

Creswell, J. W. (2017). Araştırma Deseni Nitel, Nicel ve Karma Yöntem Yaklaşımları (Çeviri Ed. Selçuk Beşir Demir. Eğiten Kitap.

Demiray, Ö.(2010). Sanal Alışveriş Mağazalarının Şikâyet Yönetiminin Müşteri Bağlılı̆̆ına Etkisi. [YayınlanmmamışYüksek Lisans Tezi]. Balıkesir Üniversitesi Sosyal Bilimler Enstitüsü.

Doğru, H., Kaygalak, S., Miral, Çavdırlı C.\& Bahçeci, V. (2014). Engelli Bireylerin Turizm Hizmetlerine Yönelik E- Şikâyetleri. Gazi Üniversitesi Turizm Fakültesi Dergisi, 2, 33-47. https://doi.org/10.17123/atad.vol26iss195912

Enginkaya, E. (2006). Elektronik Perakendecilik ve Elektronik Alışveriş. Ege Academic Review, 6(1), 11-16.

Geray, H. (2004). Toplumsal Araştırmalarda Nitel ve Nicel Yöntemlere Giriş. Siyasal Kitabevi.

Goetzinger, L. M. (2007). Consumer Complaint Behavior: Studies on Behavioral Dimensions and The Impact of The Internet. [Doctaral Thesis] Purdue University West Lafayette.

Gökdeniz İ., Bozacı İ. \& Karakaya E. (2011). Şikâyet Yönetim Süreci Sonrası Memnuniyeti Etkileyen Faktörler Üzerine Uygulamalı Bir Araştırma. Selçuk Üniversitesi Sosyal Bilimler Enstitüsü Dergisi, 26, 174-185. https://doi.org/10.18221/bujss.411694

Gökgül, M. (2014). Türkiye' de Elektronik Ticaret Ve İşletmelere, Tüketicilere Sağladığ1 Avantajlar, Dezavantajlar.[YayınlanmamışYüksek Lisans Tezi]. İstanbul Kültür Üniversitesi Sosyal Bilimler Enstitüsü.

Heppell, M. (2006). Tek Yıldızlı Bütçeyle Beş Yıldızlı Müşteri Memnuniyeti Sağlayan Büyüleyici Hizmet, (Çev. Ġ. Gülfidan. Optimist Yayın Dağıtım.

https://covid19.saglik.gov.tr/. (Erişim Tarihi: 12.06.2020).

https://www.digitalplanet.com.tr/tr/blog/koronavirus-salgini-ile-gelisen-eticaret-dunyasi-veedonusum-cozumleri-6956, (Erişim Tarihi: 30.05.2020).

İbiş, S., Kızıldemir, Ö. \& Çöp, S. (2019). İstanbul'daki Çin Restoranlarına Yönelik Yapılan Yorumların ve E-Şikâyetlerin Değerlendirilmesi. Journal of Tourism and Gastronomy Studies, 7 (1), 505-521. https://doi.org/10.21325/jotags.2019.375 
İnan, H.\& Özel, Ç. (2019). Fitness İşletmelerine Yönelik E-Şikâyetlerin İçerik Analizi İle İncelenmesi. Spor ve Performans Araştırmalart Dergisi, 10(3), 282-300. https://doi.org/10.17155/omuspd.522071

İzgi, Ç. (2018). Türkiye Ekonomisi Açısından Elektronik Ticaret: Sorunlar ve Fırsatlar.[ YayınlanmamışYüksek Lisans Tezi]. Kahramanmaraş Sütçü İmam Üniversitesi Sosyal Bilimler Enstitüsü.

Karadeniz, M. \& Iş̧1k, M.(2014). Lojistik Hizmet Kalitesi İle Müşteri Memnuniyeti İlişkisi: ETicaret Üzerine Bir Araştırma. İstanbul Sosyal Bilimler Dergisi, 7, 1-24. https://doi.org/10.17755/esosder.54015

Karagöz, Y. (2017). SPSS ve AMOS Uygulamalı Nitel-Nicel-Karma Bilimsel Araştırma Yöntemleri. Nobel Yayıncilik.

Kayabaşı, A. (2010). Elektronik (Online) Alışverişte Lojistik Faaliyetlere Yönelik Müşteri Şikâyetlerinin Analizi ve Bir Alan Araştırması. Işsletme Araştırmaları Dergisi, 2 (2), 21-42.

Kılıç, B. \& Ok, S. (2012). Otel işletmelerinde müşteri şikâyetleri ve şikayetlerin değerlendirilmesi. Journal of Yasar University, 25(7), 4189-4202.

Koçak, F.F. (2008). Kozmetik Ürünleri Pazarlama da Yeni Bir İmkân: Elektronik Ticaret. Ticaret Turizm Ĕ̈itim Fakültesi Dergisi, 2, 15-33.

Kozak, M. (2007). Turizm Sektöründe Tüketicilerin Şikâyetlerini Bildirme Eğilimleri. Yönetim ve Ekonomi, 14(1), 137-151.

Köse, E. (2007). Müş̧teri Sadakati Sağlamada Araçsal Bir Yöntem Olarak Şikâyet Yönetimi.[Yayınlanmamış Yüksek Lisans Tezi]. Marmara Üniversitesi Sosyal Bilimler Enstitüsü.

Kutluk, A. \& Arpacı, Ö. (2016). E-Wom Bağlamında Seyahat Acentalarına Yönelik E-Şikâyetlerin Gömülü Teori Ve İçerik Analizi İle İncelenmesi. Balıkesir Üniversitesi Sosyal Bilimler Enstitüsü Dergisi, 19 (35), 367-386. https://doi.org/10.31795/baunsobed.645303

Ndubisi, N. O. \& Ling, T.Y. (2006). Complaint Behaviour of Malaysian Consumers, Management Research News, 29, 65-76. https://doi.org/10.1108/01409170610645457

Özbay, G. \& Sarıca, V. (2020). Yiyecek İçecek İşletmelerinde Şikâyet Yönetimi Uygulamaları: Sakarya Örneği. Türk Turizm Araştırmalarl Dergisi, 4(2): 856-880. https://doi.org/10.26677/tr1010.2020.370

Özenç M. \& Özenç E.G. (2013). Türkiye'de Üstün Yetenekli Öğrencilerle İlgili Yapılan Lisansüstü Eğitim Tezlerinin Çok Boyutlu Olarak İncelenmesi. Türkiye Sosyal Araştırmalar Dergisi 171, 13-28. https://doi.org/10.17679/iuefd.17365583

Patterson, P. G., Lester W. J. \& Richard A. S. (1997). Modeling the Determinants of Customer Satisfaction for Business-to-Business Professional Services. Academy of Marketing Science, 25(1), 4-17.

Singh, J. (1988). Consumer complaint intentions and behavior: Definitional and taxonomical 1ssues, Journal of Marketing, $52 \quad$ (1), 93-107. https://doi.org/10.1177/002224298805200108

Şahin Başfırıncı, Ç. (2008). "Bir Pazarlama İletişim Medyası Olarak Web Ortamında İçerik Analizi Yapmanın Güçlükleri ve Olası Çözüm Önerileri”, Yönetim, Y11: 19, Sayı: 61, Ekim, s. 52 71. 
Turan, A.H. (2008), "İnternet Alışverişi Tüketici Davranışını Belirleyen Etkenler: Geliştirilmiş Teknoloji Kabul Modeli (E-TAM) ile Bir Model Önerisi”, Akademik Bilişim 2008, Çanakkale 18 Mart Üniversitesi, Çanakkale, 30 Ocak- 01 Şubat, pp.723-731.

Tübsiad (2019). Türkiye'de E-Ticaret 2019 Pazar Büyüklüğü. http://www.tubisad.org.tr/tr/images/pdf/tubisad_eticaret_2019_pazar_buyuklugu_raporu.pdf ( Erişim Tarihi: 03.06.2020).

Uzun, M. (2018). Müssteri Memnuniyeti Sağlamada Müşteri Şikâyetleri Yönetiminin Etkisi: Online Alışverişler Üzerine Bir Araştırma. [ Yayınlanmamış Yüksek Lisans Tezi]. Afyon Kocatepe Üniversitesi Sosyal Bilimler Enstitüsü.

World Healt Organization (WHO), (2020a, Haziran,12). "Coronavirus disease (COVID-19) Situation Report $\quad-\quad 144, \quad$ https://www.who.int/docs/defaultsource/coronaviruse/situation-reports/20200612-covid-19-sitrep144.pdf?sfvrsn=66ff9f4f_4 (Erişim Tarihi: 12.06.2020).

World Healt Organization (WHO), (2020b, Mart,11). "Coronavirus disease 2019 (COVID-19) Situation Report - 51, https://www.who.int/docs/default-source/coronaviruse/situationreports/20200311-sitrep-51-covid-19.pdf?sfvrsn=1ba62e57_10. (Erişim Tarihi: 20.04.2020).

Wimmer, D.D. \& Dominick, J.R. (2000). Mass Media Research: An Introduction, Wadsworth Publishing Company, Belmont.

www. sikayetvar.com

www.maxqda.com

Yanar Gürce, M. \& Tosun, P. (2017). Kargo hizmetlerine ilişkin müşteri şikâyetleri: Bir içerik analizi. İşletme Araştırmaları Dergisi, $\quad 9(3), \quad$ 177-196. https://doi.org/10.20491/isarder.2017.294

Yıldırım, A. \& Şimşek, H. (2011). Sosyal Bilimlerde Nitel Araştırma Yöntemleri, Seçkin Yayıncilik.

Zemke, R. \& Anderson, K. (2007). Delivering Knock Your Socks off Service (4th ed.). American Marketing Association Publication. 